\title{
Bartosz Rakoczy*
}

\section{COMPARATIVE STUDIES OF CANON LAW}

\begin{abstract}
To sum up, it should be noted that comparative studies of canon law can be carried out in various directions, starting from families of laws and ending with the theory of philosophy and practice. Canon law practice itself recognizes the need for such studies although their purpose is different from that of typical comparative studies. Identification of canon law as a system of law is crucial to canon law practitioners. It should be achieved by searching for specific elements in secular legal systems.

Comparative studies of canon law can be divided into external and internal studies. The first compare canon law either with secular legal orders or with other systems of confessional law. Internal comparative studies focus on internal comparative analyses of canon law. They can also be carried out with reference to the law of the Latin Church and the Eastern Churches and with reference to particular law and the internal law of institutes of consecrated life and societies of apostolic life.
\end{abstract}

\section{Keywords}

canon law - comparative studies in canon law - theory of canon law

\footnotetext{
* Professor Doctor Habilitated in Environmental Protection Law; Head of the Chair of Environmental Protection Law at the Nicolaus Copernicus University in Torun; Legal Advisor.
} 
Comparative studies have been developing in jurisprudence more and more vigorously. The development of this direction, at least in Europe, is furthered by the legislation of the European Union, which, in actual fact, aims at the closest possible harmonisation of the legal orders of respective member states ${ }^{1}$. Comparative studies with reference to systems of civil law ${ }^{2}$ are not a new invention. Such studies are carried out in various fields and at different levels.

However, the issues of comparative canon law are worth closer investigation. This is also not a new approach in canon law. According to R. Sobański "[c]anon law practitioners, who claim that ecclesiastical law and civil law are analogous, mean that both systems share certain characteristics but differ in other aspects. They make this conclusion about analogies adopting civil law as the known realm and making it a reference point for studying ecclesiastical law. However, this is only a way of identifying the characteristics of ecclesiastical law which are equivalent to the characteristics of civil law. Specific characteristics of ecclesiastical law cannot be determined on such grounds. [...] But if we take a closer look at using analogy in literature related to canon law, we notice that it is not about comparing the studied object with the known one but rather about comparing two known objects: ecclesiastical and civil law or an abstract or a priori legal concept. Such a comparison leads to statements concerning ecclesiastical law; thus, it is a certain method of cognition" 3 . Therefore, there is more than one reason supporting the need for such scientific research. Canon law is a defined legal system framed by legal norms of various natures. However, all the norms of canon law constitute a coherent system, similar to civil law systems. Canon law comprises groups of regulations governing respective institutions. Thus, comparative

1 See R. Adam, M. Safjan, A. Tizzano, Zarys prawa Unii Europejskiej [Outline of the Law of the European Union], Warszawa: Wolters Kluwer 2014.

2 This term is also used to signify legal orders other than legal orders of religious organisations. E. Szafrowski in his classification of law noted: "[h]uman law is authored by man. If it is issued within a temporal community, it is referred to as secular law (sometimes civil law), whereas if it is issued by the church authorities it is called ecclesiastical law (or canon law)" - idem, Podręcznik prawa kanonicznego [A Handbook of Canon Law], vol. I, Warszawa: Wydawnictwo Akademii Teologii Katolickiej 1985, p. 26.

3 R. Sobański, Nauki podstawowe prawa kanonicznego. Teologia prawa kościelnego [The Fundamental Teachings of Canon Law. Theology of Ecclesiastical Law], vol. 2, Warszawa: Uniwersytet Kardynała Stefana Wyszyńskiego 2001, p. 136. 
studies can be carried out at all possible levels. On the other hand however, the canon law system is peculiar since it has its specific characteristics with axiology and links to theology being the most significant from the comparative point of view.

This paper aims to identify the possibilities of performing comparative studies in canon law with emphasis on its specific and unique characteristics. This article will focus on theoretical issues of comparative studies in canon law.

Contemporary jurisprudence has not found a clear-cut and satisfactory solution to the problem of comparative studies 4 . A group of authors claims that comparative studies are simply a method for the analysis of law. Others define comparative studies as an autonomous discipline of jurisprudence next to history, legal dogma and theory of law ${ }^{5}$. The second approach expressly uses the term "comparative law"6.

Without going into further polemics regarding the meaning of the term "comparative studies", from the analysed point of view comparative studies should be interpreted as a method for the analysis of law. Making this assumption the starting point it is possible to analyse the specific characteristics of canon law in particular with reference to the civil law order.

To commence further deliberations it is necessary to define canon law. The literature related to canon law provides objective and subjective definitions of canon law. T. Pawluk notes: "[i]n objective terms canon law is a set of laws enacted by a competent ecclesiastical authority to guard the unity of the Christian community and the faithful supporters of the Church in pursuing its objectives. [...] Canon law can have a subjective meaning. In subjective terms canon law is the authority given to the Church community and its members under objective canon law"7.

\footnotetext{
4 These issues were analysed e.g. by R. Tokarczyk, Komparatystyka prawnicza [Comparative Law], Kraków: Zakamycze 2005.

5 A. Kozak, [in:] A. Bator (ed.), Wprowadzenie do nauk prawnych. Leksykon tematyczny [Introduction to Jurisprudence. A Thematic Lexicon], Warszawa: LexisNexis 2012, p. 25

6 M. Rainer, Corso di sistemi giuridici comparati [A Lecture on Comparative Law], Torino: Giappichelli 2004, p. 23 et seq.

7 T. Pawluk, Prawo kanoniczne wedtug Kodeksu Jana Pawła II. Zagadnienia wstępne i normy ogólne [Canon Law according to the Code of John Paul II. Preliminary Issues and General Norms], vol. I, Olsztyn: Włocławskie Wydawnictwo Diecezjane 2002, p. 27, 28.
} 
Thus, it can be deemed a system of law, which in the theory of law is defined as all standards in force at a specific time, in a specific country ${ }^{8}$ (community).

The theory of comparative law assumes that the subject of comparative studies is families of laws 9 . At the same time many doubts are reported regarding identification of the families of laws and in consequence - their classification $^{10}$. Many classifications refer to the Roman family. Such a highlight on the point of view of comparative canon law significantly means that canon law can be classified in this family of laws. The relationship between canon law and Roman law is not only significant in terms of history and law, since contemporary practices of canon law attach great importance to this relationship, but also from the point of view of applications of contemporary canon law ${ }^{11}$.

A consequence of this close relationship between Roman law and canon law is a huge confluence of legal institutions, terminology, understanding, and operation of the legal system. A. Dębinski indicates that the effect of Roman law on the codifications of the law of the Latin Church is revealed in the taxonomy, legal rules, definitions, and terminology and court procedure ${ }^{12}$.

Classifying canon law in the Roman law family determines the way it should be analysed using comparative methods. Comparative studies with reference to other legal systems from the Roman law family (e.g. Italian law) will differ from such an analysis with reference to the German law family or other families of laws, depending on the classification. An example of a different approach to certain juridical issues which had an impact on canon law is the calculation of the degree of kinship. Canon law adopts the commutation characteristic of Roman law ${ }^{13}$.

8 L. Morawski, Wstęp do prawoznawstwa [Introduction to Jurisprudence], Torun: TNOiK 2011, p. 67.

9 Tokarczyk, supra note 4, p. 73 et seq.

10 Ibidem.

11 Cf. A. Dębiński, Kościót i prawo rzymskie [The Church and Roman Law], Lublin: KUL 2008.

12 Ibidem, p. 113 et seq.

13 Cf. K. Kolańczyk, Prawo rzymskie [Roman Law], Warszawa: LexisNexis 2007. 
A significant characteristic of canon law is not only its temporal, but also spiritual dimension. Indeed, it can be noticed that it is a determinant of the specific nature of canon law ${ }^{14}$. The doctrine of canon law also points to the existence of the theology of canon law ${ }^{15}$. "(...) Law is a subject of theology since (1) it is one of the core terms in theology and (2) constitutes an element of reality in which man lives. Law is not «theologically neutral»; it is (also) subject to theological cognition the results of which are integrated and synthesized by the theology of law"16.

This circumstance significantly determines not only specific juridical solutions, but also the scope of the matter of interest to the ecclesiastical legislator. This circumstance is significant from the point of view of comparative studies since they can also be carried out at the level of respective legal institutions. Considering this specific characteristic of canon law, three groups of regulations can be distinguished with regard to relations between canon law and civil legal order ${ }^{17}$. The first group of regulations includes standards governing the matter characteristic of canon law only (e.g. issues related to the law of sacraments, although with certain exceptions such as reconciliation). The second group of regulations refers to the matter governed by civil law only (e.g. organisation of public authority). Finally, there is a third group of regulations applicable to the so-called mixed forum. This is the legal matter that is of interest both to the ecclesiastical legislator and civil legislator (e.g. marriages). This problem was also brought up in the literature related to a secular theory of law. A. Łopatka noticed that "[i]t [i.e. canon law - note by B.R.] governs the appointment to and dismissal from official positions in church, the rights and obligations of the followers, operations of societies and associations formed by the followers, the situation of the clergy in the Church, the structure of official functions in the Church, the existence and organisation of particular churches, the organisation and functioning of religious orders

14 P. Moneta, Introduzione al. Diritto canonico [Introduction to Canon Law], Torino: Giappichelli 2007, p. 10.

15 Sobański, supra note 3, p. 9 .

16 Ibidem, p. 10.

17 Ibidem. 
and so-called secular institutes, Church-run education, sacraments, places of worship, church holidays, the administration of Catholic cemeteries, the temporal goods of the Church, offences and penalties in the Church, ecclesiastical jurisdiction etc. It is evident that these are mostly causes that are neutral from the point of view of the Polish state and are not regulated by the laws of Poland. Thus, the problem of co-regulation or a clash of Polish law and ecclesiastical law does not exist. However, canon law governs certain matters that are regulated by Polish law. This primarily refers to marriage, education, the administration of cemeteries, and the property of the Church. In some of these matters both legal systems coincide. In the Church, marriage is one of the sacraments"18.

Taking these three groups of regulations into account, seemingly comparative matter refers only to the mixed forum that is of interest both to the secular and ecclesiastical legislator. Both the case law and writing seem to support the reasonableness of this conclusion prima facie. It is clear that comparative canon law takes an interest in the institution of marriage. This is emphasised by the above-quoted statement of A. Łopatka who claims that marriage is one of the fundamental elements, being the point of contact between canon law and the law of Poland. The similarities and differences in genere between respective elements are investigated, along with obstacles to contracting a marriage, the legal form of marriage etc.

The development of this direction is also fostered by case law in which a thread of legal consequences of contracting a marriage can be observed for both legal orders at the same time. An example may be the decree of the Supreme Court of 17 November 2000, V CKN 1364/0019, the reasoning of which states that "[a] decision of the ecclesiastical court concerning the validity or cessation of canonical marriage cannot have a prejudicial effect on the decision of the state court concerning the validity or cessation of a secular marriage".

18 A. Łopatka, Prawoznawstwo [Jurisprudence], Warszawa: Polskie Wydawnictwo Prawnicze Iuris 2000, p. 141-142.

19 Orzecznictwo Sądu Najwyższego - Izba Cywilna [Decisions of the Supreme Court - Civil Chamber; OSNC] 2001, no. 9, item 126. 
The legislator inspires such studies on its own, for instance adopting the possibility of contracting a marriage in the presence of an ecclesiastic representing a religious organisation which is provided for in Article 1 of the act of 25 February 1964 - The Family and Guardianship Code 20.

On the other hand, comparative studies of canon law cannot be limited only to the so-called mixed forum, although this is an area in which they are the easiest. In addition, such studies can and even should cover issues that are reserved either exclusively to the ecclesiastical legislator or exclusively to the civil legislator. Comparative law studies can be illustrated by issues related to the disposal of the property of ecclesiastical bodies corporate. Apparently this issue has been left to the exclusive competence of the ecclesiastical legislator. Nevertheless, as illustrated by practice and case law ${ }^{21}$, these issues are also of interest to the Polish law enforcement authorities. Canon law provides for an institution of alienation of property which has no equivalent in Polish law ${ }^{22}$. Thus, comparative studies are apparently impossible due to the lack of an equivalent to the institution of alienation in Polish law. Meanwhile, the practice and the case law demonstrate that the problem of alienation of property in canon law refers to a number of institutions of Polish civil law which are necessary for the purposes of evaluating and, as a consequence, enabling comparative studies. As an example it can be indicated that the alienation of property in canon law also covers the admissibility of charging the property of ecclesiastical bodies corporate, including the establishment of easements. Thus, comparative law studies can be carried out, for instance, with reference to the conditions under which property is charged. Of course these conditions are differently devised and follow from different legislative motives; however, this does not

\footnotetext{
20 Dziennik Ustaw [Journal of Laws] 2012, No. 788, consolidated text.

${ }^{21}$ For more information see B. Rakoczy, Prawo kanoniczne w orzecznictwie sąów polskich [Canon Law in the Case Law of Polish Courts], [in:] D. Walenciak (ed.), Prawo wyznaniowe $w$ Polsce (1989-2009). Analizy - dyskusje - postulaty [Ecclesiastical Law in Poland (1989-2009). Analyses - Discussions - Postulates], Katowice - Bielsko-Biała: Wyższa Szkoła Bankowowści i Finansów 2009, pp. 275-285.

22 The problem of alienation of property was analysed in detail in the latest literature by L. Światło, Alienacja majątku kościelnego w diecezjach rzymskokatolickich w Polsce [Alienation of Ecclesiastical Property in Roman Catholic Dioceses in Poland], Olsztyn: SQL 2010 and references quoted therein.
} 
preclude the possibility of investigating them. Against the background of the alienation of property in canon law also wider comparative studies can be carried out with regard to selling and buying property. The literature concerning canon law often makes reference to legal institutions and constructs for the purposes of identifying similarities and differences in the system of canon law ${ }^{23}$.

Comparative studies can also focus on theoretical and philosophical as well as on conceptual aspects.

As mentioned above, a group of issues is reserved for the exclusive competence of the state authorities such as, for instance, the organisation of public administration. These issues are neutral to the ecclesiastical legislator and the organisation of state administration is not regulated by canon law. However, this does not mean that the ecclesiastical legislator cannot regulate the operation and organisation of church administration and they even should and do as a matter of fact. Doctrine actually indicate the existence of administrative canon law ${ }^{24}$. Although the organisation of church administration is not related in any way to the organisation of public administration, certain similar elements of theory and construction can be identified. An example could be the issues of decentralization and deconcentration. Of course in canon law these issues are perceived differently from the way they are in the doctrine of administrative law. However, this does not diminish the possibility of carrying out comparative studies also in this area. It is not possible to study the organisation of public administration, since the structure of such organisation in the system of civil law and canon law is completely different; however, theoretical directions can be studied. R. Sobański himself pointed to the issues of administrative law as an example of using analogy 25 .

Thus, in view of the aforementioned division of causes into mixed causes, causes reserved exclusively to the ecclesiastical legislator

\footnotetext{
23 E.g. V. De Paolis, I beni temporali della Chiesa [Temporal Goods of the Church], Bologna: Edizioni Dehoniane Bologna 2011.

${ }_{24}$ For instance the excellent monograph by J. Krukowski, Administracja w Kościele. Zarys kościelnego prawa administracyjnego [Administration in the Church. An Outline of Ecclesiastical Administrative Law], Lublin: KUL 1985.

25 Sobański, supra note 3, p. 136.
} 
and causes reserved exclusively to the secular (civil) legislator, it can be assumed that these three areas can be subject to comparative studies. Naturally, comparative studies focus on issues classified as shared causes (causae mixti fori). But the above-given examples also make it possible to conclude that institutions, regulations, concepts, theories etc. which fall into the domain of the exclusive competence of the ecclesiastical legislator or the exclusive competence of the secular legislator can also be areas of interest for comparative studies.

References to civil law are significant in terms of comparative studies of canon law. Ecclesiastical legislators are aware that they are not able and do not need to regulate issues to which normative solutions adopted by civil law can be applied. Such an approach is also a manifestation of another significant characteristic of canon law - namely, its universal nature. Canon law, as a rule, is applied identically throughout the Latin Church or the Eastern Churches, a fact which will be discussed hereinafter ${ }^{26}$.

Thus, the universal nature of canon law necessitates its openness to secular legal orders under which the addressees of the norms of canon law must live. The natural corollary is the far-reaching flexibility of ecclesiastical legislators and their openness to the civil law. As far as civil law systems are concerned, they have different approaches to the norms of canon law and the theory of ecclesiastical law presents a varied approach to the effects of the norms of canon law on secular civil orders ${ }^{27}$.

Such a universal nature and such flexibility of canon law constitute a significant determinant of comparative studies ${ }^{28}$, since comparative studies can either analyse the said approach of the legislator and openness or lack of openness with reference to a different legal order. The openness of the ecclesiastical legislator to norms of civil law leads to the incorporation of civil law norms into canon law which is beyond the control of the ecclesiastical legislator. Paradoxically a norm of canon

\footnotetext{
26 See J.A. Coriden, An Introduction to Canon Law, New York/Mahwah: Paulist Press 2004.

27 These issues are analysed in detail by M. Pietrzak, Prawo wyznaniowe [Ecclesiastical Law], Warszawa: LexisNexis 2013.

28 This problem was examined by, among other authors, R. Sobański, Prawo kanoniczne a krajowy porzadek prawny [Canon Law and the National Legal Order], Państwo i Prawo [State and Law] 1999, no. 6, pp. 3-17.
} 
law will be both a norm of Polish law and, for instance, Italian or German law if, under the applicable norms of canon law, civil law was canonized. Thus, it is possible to examine how a norm of German law was canonized to canon law and what the consequences of such canonization were, and how a norm of Polish law was canonized and what the consequences of such canonization were.

Such studies are possible only with reference to canon law, which enables the canonization of different orders of civil law. The theory of comparative studies indicates that its subject can be both the norms of substantive law and the norms of procedural law ${ }^{29}$. Also, the degree of similarity or discrepancy between respective elements can be completely different with reference to procedural norms and completely different with reference to norms of substantive law ${ }^{30}$. This is similar in canon law.

The norms of procedural law are deeply rooted in Roman civil procedure underlying the procedures of legal orders classified in the family of Roman law. The comparative approach visible in this dimension refers to different procedures in so-called matrimonial causes. Here, the most significant element is proceedings for the annulment of marriage. Such proceedings are often compared with proceedings for divorce although the objective scope of both types of proceedings is completely different. However, writings contain clear attempts at explaining the procedural institutions of the proceedings for the annulment of marriage and references to proceedings in a civil court ${ }^{31}$. Of course it is difficult not to see certain shared elements such as, for instance, the adversary and contradictory nature of such proceedings, their court

29 E.g. K. Lubiński, Przedmiot komparatystyki prawa procesowego [The Subject of Comparative Studies of Procedural Law], [in:] Proces cywilny. Nauka - kodyfikacja - praktyka. Księga jubileuszowa dedykowana Profesorowi Feliksowi Zedlerowi [Civil Proceedings. Teaching Codification - Practice. A Jubilee Book Dedicated to Professor Feliks Zedler], Warszawa: Wolters Kluwer 2012, p. 2.

30 Ibidem, p. 3.

31 Cf. P. Kasprzyk, [in:] H. Cioch, A. Dębiński, J. Chaciński (eds), Unieważnienie małżeństwa w polskim prawie rodzinnym a stwierdzenie nieważności matżeństwa w prawie kanonicznym, Iustitia civitatis fundamentum. Ksiega pamiatkowa ku czci Profesora Wiestawa Chrzanowskiego [Annulment of Marriage in Polish Family Law and Declaration of the Annulment of Marriage in Canon Law. Iustitia Civitatis Fundamentum. A Book in Memory of Professor Wiestaw Chrzanowski], Lublin: Towarzystwo Naukowe KUL 2003, pp. 529-553. 
character, but significant differences between these two types of proceedings do occur there.

The above-mentioned spiritual dimension of canon law as a rule excludes canon proceedings from comparative matter since they have no equivalent in any secular legal order. Of course one can notice certain procedural institutions such as, for instance, the jurisdiction of the tribunal, the term of parties to proceedings, but the object of the proceedings is at all times out of interest for the secular legislator. Canonization proceedings provide an example of the significance of spiritual goods in canon law.

The above-mentioned deliberations concerned the issues of comparative studies of canon law with reference to civil law. This area of comparative studies of canon law could be termed internal civil comparative studies. With regard to the confessional character of canon law and its religious aspects, comparative studies of canon law should also refer to other legal systems of a confessional character. It is possible and fully reasonable to carry out comparative studies of canon law against legal systems of religious organisations both Christian and non-Christian ${ }^{32}$. Studies in this field will primarily analyse the religious and theological motives characteristic of specific denominations. A legal norm, regardless of its religious nature, is always rooted in the theology of a given religion and canon law was many times referred to as external theology. It should be emphasized that in this case the comparative law analysis differs from comparative studies of canon law and secular legal orders. In this case not only legal aspects, institutions, regulations, concepts etc. but, more importantly, the theological foundations of respective legal systems may be involved.

Comparative studies of canon law with reference to systems of law applicable in other religious organisations enable the researchers to examine elements which do not exist in secular legal orders at all, e.g. sacraments, conditions for becoming a clergyman, penalties of a religious nature etc.

32 Cf. for instance M. Zyzik, Małżeństwo w prawie muzułmańskim [Marriage in Muslim Law], Warszawa: Elipsa 2003. 
As mentioned above, it is possible to separate the comparative studies of canon law understood as a comparison between canon law and civil law. At the present stage it is reasonable to formulate the term internal comparative studies of canon law. In the case of internal comparative studies, the object of comparative law analysis is canon law only. However, since this law is greatly differentiated, such a research direction is justified. In my opinion, a convincing argument for the admissibility of using the term "internal comparative studies" is the existence of two codes - the Code of Canon Law and the Code of the Canons of the Eastern Churches ${ }^{33}$. The very fact that separate codifications exist for the Latin Church and the Eastern Churches is interesting from the point of view of comparative studies. It results in matters of canon law being codified in two separate codes, as a rule independent of each other, oriented at other addressees, but established by the same superior legislative authority represented by the Bishop of Rome. The Code of the Canons of the Eastern Churches is exclusive to the extent that it contains independent legal regulations regardless of whether or not and how specific issues are regulated in the code meant for the Latin Church ${ }^{34}$. The Code of the Canons of the Eastern Churches contains its own, independent regulations which are not known in canon law and vice versa. Both codes also contain shared regulations although each of them to an exclusive, independent, and exhaustive extent.

The variety of canon law also allows interesting comparative studies to be carried out using the division of canon law into general law and particular law. In writings, particular law is defined as the law applicable to the specific territory of the Church, e.g. a diocese, church province or territorial district which belongs to the specific Episcopal Conference ${ }^{35}$.

The varied character of such particular law enables comparative studies of the sources of this type of canon law. A certain autonomy of particular churches makes it possible to independently regulate specific

33 Codex Canonum Ecclesiarum Orientalium auctoritate Ioannis Pauli PP. II promulgatus.

34 This legal act was also analysed in the context of exclusivity in the study by P.V. Pinto (ed.), Commento al. Codice dei Canoni delle Chiese Orientali [A Commentary on the Code Canons of the Eastern Churches], Città del Vaticano: Liberia Editrice Vaticana 2001.

35 Pawluk, supra note 7, p. 30. 
issues in a manner different from the particular law of another church. The construction of particular law to some extent resembles the acts of local law or executive provisions, although the analogy is definitely loose here. However, from the analysed point of view the most significant is the varied character of particular law which facilitates deeper comparative law studies.

A separate interesting category is the acts of internal law of institutes of consecrated life and societies of apostolic life. Here the diversity of institutes of consecrated life and societies of apostolic life is of significance. Perhaps there is no other matter of canon law in which legislative diversity and distinctness are as welcome as they are with reference to the internal law of institutes and societies ${ }^{36}$. Comparative research should focus on analysing similarities and dissimilarities between legislative solutions adopted in respective institutes and societies, taking into account their charisma and spirit.

To sum up, it should be noted that comparative studies of canon law can be carried out in various directions, starting from families of laws and ending with the theory of philosophy and practice. Canon law practice itself recognizes the need for such studies although their purpose is different from that of typical comparative studies. The identification of canon law as a system of law is crucial to canon law practitioners. It should be achieved by searching for specific elements in secular legal systems.

Comparative studies of canon law can be divided into external and internal studies. The first compare canon law either with secular legal orders or with other systems of confessional law. Internal comparative studies focus on internal comparative analyses of canon law. They can also be carried out with reference to the law of the Latin Church and the Eastern Churches and with reference to particular law and the internal law of institutes of consecrated life and societies of apostolic life.

\footnotetext{
36 This law was analysed in detail, e.g. by J. Kałowski, Konstytucje $i$ inne zbiory prawne instytutów życia konsekrowanego wedtug kodeksu prawa kanonicznego z $1983 \mathrm{r}$. [Constitutions and Other Bodies of Laws of Institutes of Consecrated Life According to the Code of Canon Law], Prawo Kanoniczne [Canon Law] 1986, no. 1/2, pp. 149-184.
} 
